\title{
Book Review: Final Solutions: Capitalism, Human Nature and Genocide
}

Jack D. Palmer

University of Leeds

Follow this and additional works at: https://digitalcommons.usf.edu/gsp

\section{Recommended Citation}

Palmer, Jack D. (2016) "Book Review: Final Solutions: Capitalism, Human Nature and Genocide," Genocide Studies and Prevention: An International Journal: Vol. 9: Iss. 3: 177-179.

DOI:

http://dx.doi.org/10.5038/1911-9933.9.3.1371

Available at: https://digitalcommons.usf.edu/gsp/vol9/iss3/14

This Book Review is brought to you for free and open access by the Open Access Journals at Digital Commons @ University of South Florida. It has been accepted for inclusion in Genocide Studies and Prevention: An International Journal by an authorized editor of Digital Commons @ University of South Florida. For more information, please contact digitalcommons@usf.edu. 
Book Review: Final Solutions: Human Nature, Capitalism and Genocide

Jack Palmer

University of Leeds

Leeds, United Kingdom

Final Solutions: Human Nature, Capitalism and Genocide

Sabby Sagall

London: Pluto Press, 2013

320 pp., US\$35 (pbk), US\$110 (hbk)

Reviewed by Jack Palmer

University of Leeds

\section{Introduction}

Because genocide studies came to prominence in the 1990s, it has been argued, ${ }^{1}$ it developed within the particular theoretical confines of the time and missed earlier turns in the humanities and social sciences such as those associated with Marxism, feminism or post-structuralism. Sabby Sagall's Final Solutions is an ambitious attempt at rectifying the omission of the Marxist theoretical programme in the analysis of genocide. In particular, he seeks to demonstrate the significance and value of the marriage of Karl Marx and Sigmund Freud associated with the Institut für Sozialforschung, better known as the Frankfurt School. This body of work, Sagall attempts to demonstrate, possesses a great deal of potential in terms of its capacity to shed light on the interrelationship between the objective-historical and subjective-psychological factors of collective violence. It is an ambitious book that, whilst possessing shortcomings, is a welcome addition to the literature on genocide.

Sagall's point of departure is that "only by organically linking elements from history, social theory, economics and psychology" (3) can we come to an understanding of genocide. The theoretical perspective most suitable for this task, the author argues, is Marxism, particularly its synthesis with psychoanalysis. To this end, he makes use of the valuable resources offered by Marx and Freud, as well as thinkers like Wilhelm Reich, and Frankfurt School intellectuals such as Erich Fromm and Herbert Marcuse. This is a welcome development because, as far as representations in genocide studies go, Adorno and Horkheimer and their Dialectic of Enlightenment has tended to comprise the sole inclusion of Frankfurt School thinkers into central debates in the study of genocide, particularly those regarding the relationship between genocide and modernity. In the work of Reich and Fromm, as the author augurs, are found very useful tools which can be put to use in order to illuminate how socio-economic structures and processes, funnelled through the microsocial unit of the family, embed themselves in the psyche of individuals. Sagall also incorporates the analyses of a "second generation" of psychoanalytic Marxists such as Reuben Osborn, Joel Kovel and Eugene Wolfenstein (to name a few), as well as post-Freudian psychoanalysts like Melanie Klein.

The book is split into two parts of four chapters each. The first outlines the theoretical framework of the study over four chapters. Firstly, under the heading "Why do People Kill People?" Sagall reviews a number of interpretations of the macro features of genocide in different disciplines and identifies their strengths and weaknesses. He then goes on to discuss representatives of the microanalysis of genocide under the title "Killers on the Couch." These first two chapters set up Sagall's own contribution, borne of a dissatisfaction with those who "affirm that destructiveness is an ineradicable part of human nature as against those who seek its roots in social conditions" (68).

In the third chapter, "What Makes Killers Tick?" the author lays out his own approach, introducing Erich Fromm's notion of "social character," predominantly reproduced in the family unit, which operates as a mediating link between the poles of social structure and individual agency. Collectivities are characterised as possessing a "social character" which can sometimes

${ }^{1}$ Martin Shaw, Genocide and International Relations: Changing Patterns in the Transitions of the Late Modern World (Cambridge: Cambridge University Press, 2013), 26. 
contain a predisposition for genocidal aggression. However, this predisposition is activated only in certain precipitating circumstances, particularly in humiliating military defeats and social and economic crises. This is a laudable move, and Sagall draws on a considerable breadth of thinkers and concepts to good effect. However, bold claims like "to my knowledge, no work attempting to link the objective and the subjective reasons for genocide has been done since the 1970s" (7) seem over pronounced. One figure who is not mentioned in this equation is the sociologist Norbert Elias, whose systematic theory of civilizing and decivilizing processes (particularly in his writings on Germany), is evoked by Sagall's desire to link the historical and psychological levels of genocide but is not engaged. ${ }^{2}$

In the fourth chapter, the final in the expository section of the thesis, Sagall discusses the notion of "Killing Things." Under capitalism, human beings become reified and appear as objects "perceived and defined in terms of their exchange-value, their price or cost, not their usefulness or intrinsic value as individual persons or objects, that is, their use value" (95). Thus, genocide is a killing of dehumanised "things" rather than people. Of the opening chapters, although intriguing, this is the least developed in terms of how it is later explored in the case studies.

The second part of the book constitutes a comparative study of four cases of genocide against which to test the framework; the Native American genocide, the Armenian genocide, the Nazi Holocaust and the Rwandan genocide. These cases are well put together, if a little loosely organized. In the case of the Native American genocide, Sagall takes care to differentiate the experience of the native populations of the Americas in their contact with social groups from Europe, possessing distinct "social characters," rather than generalising them both under a singular European coloniser (124). On the Armenian Genocide, Sagall documents how political, social and military disintegration, bought forth by varying crises, fostered violent behaviour among Young Turks: "As their inner world became more and more threatening they dealt with it by developing a social character that combined two main features: a hoarding mode of assimilation as they struggled to hang on to the glories of the Ottoman past; and a mode of relatedness that became increasingly authoritarian and destructive, brimming over with narcissistic rage, the obverse of their grandiose sense of self" (182). In the chapter on the Nazi Genocide, the author situates his own argument in relation to the longstanding intentionalist-functionalist debate in Holocaust scholarship. Following Michael Mann's idea that genocide normally constitutes a sort of "plan C," Sagall demonstrates how the Nazi genocide moved through successive phases of "problem-solving." That is, genocidal intent emerged in the context of shifting material circumstances and contingencies, each aggravating a predisposing "authoritarian social character." He finally turns his attention to Rwanda, concluding that "the Hutus were, arguably, people with powerful and rigid super-egos, unstable ids, and weak egos. However, in the orgy of killing, the super-ego transmitted the order to kill Tutsis, prompting the id to jettison its 'normal' everyday life drive and morph into its destructive self" (246).

Though in many ways an effective exploration of the cases aided by the theoretical framework developed in the first section, this part of the book nevertheless possesses shortcomings. Firstly, like the first section, it contains sections that seem digressive (for instance, the descriptive tracts on the Quakers in the chapter on genocide in the Americas and on the Madagascar plan in the chapter on the Nazi genocide). The case study struggles at times to reconcile the tension between historical description and theoretical cogency that is characteristic of this sort of ambitious empirically-informed conceptual work. Sagall also affords too much coherence and corporeality to social groups, making large generalisations on the basis of their purported social character. This is an ethical and representational issue as much as an empirical one. For instance, as Lee Ann Fujii has demonstrated, ${ }^{3}$ although tens of thousands of Rwandan Hutu participated in the 1994 genocide, many more did not kill. A further problem with this section is that it does not sufficiently take into account the transformations in global capitalism over the duration of his case studies, from its expansion into the New World from the 15th century to the imposition of IMF structural adjustment programmes in Rwanda towards the end of the 20th.

\footnotetext{
${ }^{2}$ Elias, Norbert Elias, Studies on the Germans: Collected Works of Norbert Elias (Dublin: University College Dublin Press, 2013).

${ }^{3}$ Lee Ann Fujii, Killing Neighbours: Webs of Violence in Rwanda (Ithica, NY: Cornell University Press, 2009).
} 
In general, Sagall provides a persuasive argument that navigates the pitfalls of "sociological reductionism," that is affording an over-determining capacity to social structures and processes whilst downplaying how "external, material conditions become translated into the psyche of an individual" (5), as well as of "psychological reductionism," that is the "divorce of history from psychology ... reducing historical phenomena to the psychology of the protagonists and, conversely, failing to locate their individual psychology within the wider society and its politics" (6). Psychoanalysis provides a way of exploring the "irrational" dimension of genocide, that which cannot be adequately addressed by recourse to economic or political explanations.

The distinction between rational and irrational motives for genocide is the most contentious area of the work. As Sagall defines it: "One can ... distinguish between, on the one hand, economic and political genocides, which do have a 'rational' or utilitarian basis, and, on the other, those that have little or no instrumental explanation, and can therefore be deemed 'irrational,' explicable if not only, then largely, in psychological terms" (9). Though Sagall returns to this distinction at other points in the work, it is not sufficiently elucidated. Firstly, in addition to the moot question of whether "rationality" can be disentangled from its normative connotations (thus running the risk of rendering some genocides more understandable, even acceptable, than others), those so-called "rational" modern atrocities identified are those most uneasily situated historically in relation to communism, such as those in Cambodia and the Soviet Union.

There is also a sense in which the distinction of the terms "rational" and "irrational" would have been better developed in dialogue with works in genocide studies that explicitly address notions of rationality. Jacques Sémelin's notion of "delusional rationality" is unacknowledged,4 and the idea of the dark potentiality of "instrumental rationality" which permeates Zygmunt Bauman's analysis in Modernity and the Holocaust is not satisfactorily broached. Given the significance Sagall attributes to rationality, it is surprising that the book omits a consideration of Max Weber's influence on the Frankfurt School, a figure who might be said to be comparable in influence to that of Marx and Freud, particularly his ideas on the irrationality of processes of modern rationalization. This is an idea that pervades Adorno and Horkheimer's Dialectic of Enlightenment, a book that strangely does not get much of a hearing in a book so influenced by the Frankfurt School.

Nevertheless, overall the book is a welcome contribution to genocide studies. It will be particularly useful for those readers who are interested in recent debates in genocide studies concerning the relationship between structural violence and genocide. Even taking into account its flaws, Sagall's study should be applauded for its attempt to link the violence of economic systems to the brute physical violence of genocide in a non-reductionist way.

${ }^{4}$ Jacques Sémelin, Purify and Destroy: The Political Uses of Massacre and Genocide (Columbia, NY: Columbia University Press, 2009). 